\title{
Migration and public health challenges - food consumption and vitamin D status
}

Finland is a country with a long history of emigration since 1860's (1). However, beginning in the 1990s, Finland started receiving migrants from Russia, Estonia, Somalia, Yugoslavia and more recently Afghanistan and Iraq (2). The international mobility to and from Finland has increased, particularly after the country joined the European Union in 1995 and the Schengen Agreement in 1996 (3). In the year 2015, 32000 asylum seekers were received in Finland (2). Currently, individuals with foreign background constitute $7.3 \%$ of the total population (4). The populations examined in this study, which are persons of Russian, Somali and Kurdish origin, account for over 28\% of the foreign-born population in Finland (4). The Russian origin population is the largest migrant group in Finland; Somali origin population is the fourth largest and Kurdish-speaking population is the sixth largest population of foreign origin in Finland (4). Compared to other Scandinavian countries and based on the international standards, the migrant population in Finland is small (2). Nevertheless, due to short history of migration in Finland, the current migrant population size is very significant in terms of integration challenges (2), which include their health and well-being.

The reasons for migration are usually based on economic, political, security or educational improvement. Regardless of the motive, migration is a complex process that can influence the health of migrants, both positively and negatively depending on different factors with each individual (5). Such factors may be cultural, environmental or health related. The health profiles of the immigrants are often different from those of the host populations. These have been observed in the Nordic countries with greater migrant populations such as Sweden and Norway.

In 2012, it was stated in the National Public Health Report from Sweden that people with foreign backgrounds were in poorer state of all health-related issues than those with Swedish origin (6). Likewise, poor health conditions and several risk factors related to pre- and post-migration experiences, among others, were observed in immigrant populations living in Norway (5). Some of the major health problems identified among immigrants in these countries were lifestyle and diet-related $(5,6)$. Such cases included high prevalence of obesity and overweight, diabetes and vitamin D deficiency among both adults and children $(5,6)$.

One of the key changes associated with migration is that of dietary habits and nutrient intake (5), which is mostly driven by the level of acculturation in the host countries. The process of westernization and nutritional transition of a diet high in calories, saturated fat, refined sugars and a low consumption of dietary fibers, fruits and vegetables is responsible for conditions such as obesity, diabetes and cardiovascular diseases (7-9). In Norway, both positive and negative changes were observed among South Asians immigrants from Sri Lanka and Pakistan (10). There was increase in fruit and vegetable consumption and reduction in fat intake among the higher educated immigrants (10). However, red meat consumption increased with length of residence (10).

Vitamin D insufficiency and deficiency is another major health challenge associated with migration, especially to the northern latitudes where exposure to sunlight is limited (11). Vitamin D, which is known as the "sunshine" vitamin, is important for bone health in children and adults. Its adequate status helps in the prevention of osteoporosis and fractures and decreased risk of falls $(12,13)$. On the contrary, low vitamin D status is associated with the risk of bone disorders and non-skeletal conditions such as cancers, cardiovascular disease, and type 2 diabetes (14, 
15). As migrants departed from the tropical region, leaving abundant sunlight behind, the production of vitamin $\mathrm{D}$ in the skin is affected and its concentration in the blood gradually decreases. Hence, the newly arrived immigrants to the northern countries, particularly those with darker skin from Africa and Asia, become vulnerable to vitamin D insufficiency and the associated health conditions. Moreover, the risk increases with the duration of residence.

In summertime, between April and September, exposure to sunlight and vitamin $\mathrm{D}$ production in the skin is possible at northern latitudes. Nevertheless, amount of vitamin D obtained from exposure to sunlight depends on cultural behaviours and lifestyles of the immigrant groups. Compared with the Nordic host populations, low vitamin D status among immigrants may be associated with lifestyles of limited outdoor activities and sun exposure habit. In addition, wearing of traditional clothes that cover the entire body reduce the amount of ultraviolet radiation required on the skin for vitamin D synthesis $(12,16)$. The skin colour also plays an important role, as people with darker skin need a longer sunlight exposure period of about six-fold than the fair-skinned (Caucasian) persons (17).

In the absence of sunlight, adequate vitamin D status is obtainable through dietary sources such as fatty fish, cod liver oil, vitamin D-fortified foods, which include fluid milk products and margarine, and vitamin D supplements $(13,18$ 20). Nevertheless, dietary patterns among immigrants, especially those that have been formed in their home countries, play important role in the consumption of the available sources. Reasonably, newly arrived immigrants will easily consume foods that are popular in their countries of origin. Hence, it may be difficult for immigrant groups without dietary pattern of frequent food such as fatty fish and fluid milk consumption to have substantial contribution of vitamin D intake from diet. For example, unlike the Nordic indigenous populations with tradition of fatty fish and cod liver consumption $(20,21)$, the uncommon fatty fish consumption among non-Western immigrants was associated with high prevalence of Vitamin D deficiency (21).

Likewise, lower use of vitamin D supplements was observed among immigrants of non-Western origin living in the Nordic coun- tries (21). Personally, while growing up in Nigeria, I often use multivitamin supplements. However, vitamin D supplement was never included; probably because of the endogenous synthesis in the skin upon exposure to sunlight throughout the year. I started to use vitamin D supplement here in Finland when I received information about risk of vitamin deficiency among dark skin immigrants residing in the northern latitudes. In addition, despite the effort to ensure consumption of healthy diet while in Nigeria, there was no special consideration with concerns about vitamin D status. Traditionally, fluid milk is not part of dietary pattern in West-African, except among the nomadic tribes. Hence, inclusion of fluid milk into my diet was based on adaptation into Finnish food culture and its importance as a good source of vitamin D. Except the immigrant populations living at the northern latitudes are informed, changes in dietary patterns that promote health such adequate vitamin D status may be difficult to achieve.

As public health problem in the northern countries, vitamin D intake and vitamin D status were low in Finland in time past (20). Currently, vitamin D status among the majority (that is 7791\%) of the general Finnish population is sufficient $(22,23)$. The improvement seen over the years is primarily due to fortification policy that was introduced in 2003 and the subsequent increment of the vitamin D fortification scheme for fluid milk products and respective plant-based alternatives and fat spreads in 2010 (24, 25). The report of the recent national dietary survey (FinDiet 2017) showed that vitamin D-fortified fat spreads and dairy products and fish contributed to $83 \%$ of daily vitamin D intake among Finnish men and $79 \%$ among Finnish women (26). Average daily dietary vitamin D intake among Finnish adult population was documented in the report as $13 \mu \mathrm{g}$ for men and $10 \mu \mathrm{g}$ for women (26). Hence, the current vitamin D recommendation of $10 \mu \mathrm{g}$ for children and adults is obtainable, probably through diet alone among majority of the Finnish population. Nonetheless, use of vitamin D supplements is recommended for persons of special age groups (such as children and elderly) and individuals with less vitamin D-rich foods consumption $(13,20)$.

The number of immigrants, especially the non-Western population, is increasing in Fin- 
land. However, little is known about their state of health. With the existing poorer health reports, (including diet-related diseases and vitamin D deficiency) among non-Western immigrants in other Nordic countries, the present study was carried out in anticipation to understand the situation among immigrants in Finland, in terms of dietary habits and vitamin D status. The consumption of healthy foods among immigrants with Russian, Somali, and Kurdish background was examined. The vitamin D status of the immigrant groups was evaluated in comparison to that of the general Finnish population. Moreover, ethnic differences in the effect of vitamin $\mathrm{D}_{3}$ supplementation on vitamin D status between Somali and Finnish women were investigated.

The findings of this study provided the needed nutrition information among immigrant groups in Finland, especially on food consumption patterns, vitamin D status, and associated factors. The provided information is therefore useful in the public health nutrition sector and in health policy making, especially in prevention of vitamin D insufficiency and its related diseases in Finland and internationally. Finally, this study calls for attention on dietary research among immigrants and recommends that a wide range of immigrant populations should be included in the regular national dietary surveys in Finland. Thus, there will be clearer understanding about the underlying factors in comparison with the general Finnish population. Moreover, this is important, especially when studying the second and third generations of immigrants who should be considered Finns, not immigrants.

\section{REFERENCES}

(1) Korkiasaari J. Contemporary Immigration to Finland. Institute of Migration Turku, Finland. FinnFest USA Minneapolis, MN, 2014. Accessed 27.9.2019. http://www. migrationinstitute.fi/dl/Contemporary_ Immigration_to_Finland.pdf

(2) Organisation for Economic Co-operation and Development (OECD). Finding the way: A discussion of the Finnish migrant integration system, 2017. Accessed 27.9.2019. https://www. oecd.org/els/mig/Finding-the-Way-Finland.pdf

(3) Korpela M, Rantanen P, Hyytiä J et al. Temporary migration in Finland. In Pitkänen $\mathrm{P}$ and Carrera S. (Eds.) (p. 81). Transnational migration in transition: state of the art report on temporary migration, 2014. Accessed 27.9.2019. https://social-anthropology.org. ua/wp-content/uploads/2018/11/Chorniy-P.Temporary-Migration-in-Ukraine.pdf

(4) Statistics Finland. Statistics Finland's PX-Web databases, 2019. Accessed 27.9.2019. http:// pxnet2.stat.fi/PXWeb/pxweb/en/StatFin/ StatFin_vrm_vaerak/?tablelist=true

(5) Abebe DS. Public Health Challenges of Immigrants in Norway: A Research Review. Norwegian Center for Minority Health Research, 2010. Accessed 1.10.2019. https:// www.fhi.no/globalassets/dokumenterfiler/ rapporter/2010/public-health-challenges-ofimmigrants-in-norway-nakmireport-2-2010.pdf (accessed September 2019).

(6) Hjern A. Migration and public health: Health in Sweden: The national public health report 2012. Chapter 13. Scand J Public Health 2012;40:255-267. https://doi.org/10.1177/1403494812459610

(7) Misra A, Ganda OP. Migration and its impact on adiposity and type 2 diabetes. Nutrition 2007;23:696-708. https://doi.org/10.1016/j.nut.2007.06.008

(8) Gilbert PA, Khokhar S. Changing dietary habits of ethnic groups in Europe and implications for health. Nutr Rev 2008;66:203-215. https://doi.org/10.1111/j.17534887.2008.00025.x

(9) Landman J, Cruickshank JK. A review of ethnicity, health and nutrition-related diseases in relation to migration in the United Kingdom. Public Health Nutr 2001;4:647-57. https://doi.org/10.1079/PHN2001148

(10) Wandel M, Raberg M, Kumar B, et al. Changes in food habits after migration among south asians settled in oslo: The effect of demographic, socio-economic and integration factors. Appetite 2008;50:376-385. https://doi.org/10.1016/j.appet.2007.09.003

(11) Meyer HE, Holvik K, Lofthus CM, et al. Vitamin D status in Sri Lankans living in Sri Lanka and Norway. Br J Nutr 2008;99:941-944. https://doi.org/10.1017/ S0007114507844138

(12) Ross AC, Taylor CL, Yaktine AL, et al. editors. Dietary Reference Intakes for Calcium and Vitamin D. Institute of Medicine. Washington (DC): National Academies Press, 2011.

(13) Nordic Council of Ministers. Nordic Nutrition Recommendations 2012: integrating nutrition and physical activity. 5th ed. Copenhagen: Nordic Council of Ministers, 2014.

(14) Rejnmark L, Bislev LS, Cashman KD, et al. Non-skeletal health effects of vitamin 
D supplementation: a systematic review on findings from meta-analyses summarizing trial data. PLoS One 2017;12:e0180512. https://doi.org/10.1371/journal.pone.0180512

(15) Bouillon R, Marcocci C, Carmeliet G, et al. Skeletal and extraskeletal actions of Vitamin D: Current Evidence and Outstanding Questions. Endocr Rev 2019;40:1109-1151. https://doi.org/10.1210/er.2018-00126

(16) Tsiaras WG, Weinstock MA. Factors influencing vitamin D status. Acta Derm Venereol 2011;91:115-124. https://doi. org/10.2340/00015555-0980

(17) Webb AR, Engelsen O. Calculated ultraviolet exposure levels for a healthy vitamin D status. Photochem Photobiol 2006;82:1697-1703. https://doi.org/10.1562/2005-09-01-RA-670

(18) Holick MF. Vitamin D deficiency. N Engl J Med 2007;357:266-281.

https://doi.org/10.1056/NEJMra070553

(19) Holick MF. Optimal vitamin D status for the prevention and treatment of osteoporosis. Drugs Aging 2007;24:1017-1029. doi:10.2165/00002512-200724120-00005 https://doi.org/10.2165/00002512-20072412000005

(20) Lamberg-Allardt C, Brustad M, Meyer HE, et al. Vitamin D - a systematic literature review for the 5th edition of the Nordic Nutrition Recommendations. Food Nutr Res 2013;57. https://doi.org/10.3402/fnr.v57i0.22671

(21) Wändell PE. Population groups in dietary transition. Food Nutr Res 2013;57. https://doi.org/10.3402/fnr.v57i0.21668

(22) Jääskeläinen T, Itkonen ST, Lundqvist A, et al. The positive impact of general vitamin $\mathrm{D}$ food fortification policy on vitamin D status in a representative adult Finnish population Evidence from an 11-year follow-up based on standardized 25-hydroxyvitamin D data. Am J Clin Nutr 2017;105:1512-1520.

https://doi.org/10.3945/ajcn.116.151415

(23) Raulio S, Erlund I, Männistö S et al. Successful nutrition policy: improvement of vitamin D intake and status in Finnish adults over the last decade. Eur J Public Health 2017;27:268-273. doi: 10.1093/eurpub/ckw154 https://doi. org/10.1093/eurpub/ckw154

(24) Ministry of Trade and Industry of Finland (in Finnish). Kauppa ja teollisuusministeriön asetus vitamiinien ja eräiden muiden aineiden lisäämisestä elintarvikkeisiin. [Regulation 917/2002 about adding of vitamins and some other substances to foodstuffs], 2002. Accessed 3.10.2019. http://www.finlex.fi/fi/laki/ alkup/2002/20020917

(25) National Nutrition Council. Valtion ravitsemusneuvottelukunta. D-vitamiinityöryhmän raportti. [Report of vitamin D working group.] In: Finnish, 2010. Accessed 3.10.2019. https://www. ruokavirasto.fi/globalassets/teemat/ terveytta-edistava-ruokavalio/ravitsemus--jaruokasuositukset/erityisohjeet-ja-rajoitukset/dvitamiiniraportti2010.pdf

(26) Valsta L, Kaartinen N, Tapanainen H et al. Editors. Nutrition in Finland - The National FinDiet 2017 Survey. In: Finnish, with English abstract. National Institute for Health and Welfare (THL). Report 12/2018. Helsinki, Finland: PunaMusta Oy.

\section{Folasade A. Adebayo}

MSc. Public Health Nutrition

University of Helsinki

Department of Food and Nutrition

MSc. Folasade Adebayon väitöskirja Insights into food consumption, vitamin D status and the associated factors among immigrant adult populations in Finland: findings from population-based and intervention studies (Ulkomaalaistaustaisten aikuisten ruokatottumukset, D-vitamiinitila ja niiden yhteydessä olevat tekijät - Löydöksiä väestöpohjaisista ja interventiotutkimuksista) tarkastettiin Helsingin yliopiston maatalous-metsätieteellisessä tiedekunnassa 11.10.2019. Vastaväittäjänä toimi Dr Inez Schoenmakers (University of East Anglia, Iso-Britannia) ja kustoksena professori Mikael Fogelholm (Helsingin yliopisto). Sosiaalilääketieteellinen aikakauslehti julkaisee lektio praecursorian poikkeuksellisesti muulla kuin kotimaisilla kielillä kirjoittajan äidinkielen vuoksi. 